Soybean Oil 및 Flaxseed Oil 첨가 배양시 탄수화물 첨가수준에
의한 반추미생물의 Bio-hydrogenation과 CLA 생성에 미치는 효과

최성호 · 임근우 · 김광림 · 송만강

충북대학교 농업생명환경대학 축산학과

\title{
Effect of the Level of Carbohydrates on Bio-hydrogenation and CLA Production by Rumen Bacteria When Incubated with Soybean Oil or Flaxseed Oil In vitro
}

S. H. Choi, G. W. Lim, G. L. Jin and M. K. Song

Department of Animal Science, Chungbuk National University, Korea

\begin{abstract}
An in vitro study was conducted to examine the effect of addition level of carbohydrates on fermentation characteristics, and bio-hydrogenation of unsaturated fatty acids by mixed rumen bacteria when incubated with soybean oil or flaxseed oil. Four levels $(0 \%, 0.3 \%, 0.6 \%$ and $0.9 \%$, w/v) of the mixed carbohydrates(glucose, cellobiose, soluble starch, 1:1:1, in weight basis) and oil sources(soybean or flaxseed oil, $60 \mathrm{mg}$ in $150 \mathrm{ml}$ culture solution) were added to the mixed solution of strained rumen fluid with artificial saliva(1:4, v/v), and incubated anaerobically for 12 hours at $39^{\circ} \mathrm{C} . \mathrm{pH}$ and ammonia-N concentration were lower by increasing the substrate levels at all incubation periods $(\mathrm{P}<0.05 \sim \mathrm{P}<0.001)$. The propionate proportion increased $(\mathrm{P}<0.001)$, but acetic acid and butyric acid $\operatorname{decreased}(\mathrm{P}<0.001)$ with the substrate level at 6 and $12 \mathrm{~h}$ incubations. Oil sources did not influence the proportions of individual VFA. At the end of incubation, the proportions of $\mathrm{C}_{18: 0}(\mathrm{P}<0.01), \mathrm{C}_{18: 1}(\mathrm{P}<0.001)$ and trans-11C-18:1 $(\mathrm{P}<0.01)$ were reduced but those of $\mathrm{C}_{18: 2}(\mathrm{P}<0.001)$ and $\mathrm{C}_{18: 3}(\mathrm{P}<0.01)$ were enhanced by the addition of flaxseed oil compared to addition of soybean oil. The proportions of $\mathrm{C}_{18: 0}$ and total CLA were reduced $(\mathrm{P}<0.01)$ but those of trans-11- $\mathrm{C}_{18}$ : $(\mathrm{P}<0.05)$ and $\mathrm{C}_{18: 2}(\mathrm{P}<0.01)$ were increased with the substrate level when incubated with soybean oil or flaxseed oil. There were interactions $(\mathrm{P}<0.05)$ in the proportions of $\mathrm{C}_{18: 1}, \mathrm{C}_{18: 2}$ and $\mathrm{C}_{18: 3}$ $(\mathrm{P}<0.01)$ between oil source and substrate level. The proportions of cis-9, trans-11-CLA and trans-10, cis-12-CLA tended to reduce with substrate level, although there was no significant difference between treatments.
\end{abstract}

(Key words : CLA, Rumen microbes, Bio-hydrogenation, Flaxseed oil, Soybean oil, In vitro)

\section{I. 서 론}

지난 이십여 년 동안 각종 실험동물 및 일부 인간을 대상으로 한 임상실험을 통해 conjugated linoleic acid(CLA)는 항암효과(Ha 등, 1987), 면
역능력증진(Cook 등, 1993), 항 동맥경화(Lee 등, 1994), 체구성 변화(Park 등, 1997) 등의 효과로 주목 받아왔다. CLA는 17 개 이상의 이성체가 있는 것으로 알려지며(Banni 과 Martin, 1998), 그 중 cis-9, trans-11 CLA와 trans-10, cis-12

Corresponding author : Man-Kang, Song, Department of Animal Science, Chungbuk National University, 12 Gaeshin-dong, CheongJu, Chungbuk, 361-763, Korea.

Tel : 043-261-2545, E-mail : mksong@cbnu.ac.kr 
CLA의 생성량은 물론 역가도 가장 높은 것으 로 알려져 왔다(Steinhart, 1996).

자연적으로 $\mathrm{CLA}$ 는 사료로 섭취된 $\mathrm{C}_{18}$ 계 다 중 불포화지방산이 반추위 미생물들에 의해 가 수소화반응(bio-hydrogenation)이 되면서 형성된 다(Harfoot와 Hazlewood, 1988). 반추위내에서의 CLA의 형성에 사용되는 불포화지방산은 주로 linoleic acid라고 알려져 왔지만(Kelly 등, 1998), Bessa 등(2000)은 linolenic acid로부터도 CLA가 형성될 수 있을 것으로 추정하였다. Wang 등 (2002a, 2002b)과 Choi와 Song(2005)은 linolenic acid로부터 CLA가 생성될 수 있음을 확인 한 바 있다.

반추위 미생물의 bio-hydrogenation 조절을 통 한 CLA 생성을 극대화시키기 위해 다양한 연 구가 실시되었는데, linoleic acid가 다량 함유된 식물성 oil의 선택(Wang 등, 2003, Choi 등, 2006)을 제외하고는 대부분 농후사료와 조사료 의 급여 비율조절(Wang 등, 2002b; Dhiman 등 1999; Choi 등 2005)에 관한 연구가 주류를 이 루었다. 이들 실험에서는 공통적으로 반추위액 의 $\mathrm{pH}$ 가 CLA 생성에 매우 중요한 요인이라고 하였는데, 이러한 반추위액의 $\mathrm{pH}$ 는 주요 에너 지원으로 사용되는 탄수화물의 종류(Latham 등, 1972), 발효 속도(Martin과 Jenkins, 2002), 가공 방법(Fellner 등, 1995) 등에 따라 특징을 달리 하며, 이에 관련된 반추미생물의 성장 역시 변 화되는 반추위액의 $\mathrm{pH}$ 에 매우 민감하다고 보 고 된 바 있다(Harfoot와 Hazlewood, 1988).

앞에서 살펴본 바와 같이, 반추위 미생물에 의한 가수소화 반응을 조사한 실험은 주로 linoleic acid의 공급원과 탄수화물 공급원의 종 류 등에 따른 $\mathrm{pH}$ 변화와 관련된 것이었다. 그 러나 현재까지 linoleic acid 또는 linolenic acid 가 다량 함유된 oil을 첨가하고 탄수화물원의 첨가량을 달리 하였을 때 반추미생물에 의한 CLA 생성 및 bio-hydrogenation에 어떻게 영향 하는가를 조사한 연구는 미흡하다.

따라서 본 연구는, 반추위내 $\mathrm{pH}$ 에 영향할 수 있는 탄수화물원을 여러 수준으로 첨가하고, 여기에 반추위에서 CLA의 전구물질로 알려진 불포화지방산 즉, linoleic acid 또는 linolenic acid를 다량 함유하고 있는 대두유(soybean oil) 또는 아마유(flaxseed oil) 첨가가 발효성상, biohydrogenation 및 CLA 생성에 어떻게 영향하는 지를 조사하고자 실시되었다.

\section{ㅁ. 재료 및 방법}

\section{1. 실험설계}

본 실험은 in vitro 방법으로 수행 되었다. 처 리구로는 탄수화물 첨가수준과 첨가하는 oil의 종류를 달리하는 2가지 요인을 두었다. 배양액 내 탄수화물원의 첨가수준은 $0 \%, 0.3 \%, 0.6 \%$, 그리고 $0.9 \%(\mathrm{w} / \mathrm{v})$ 로 하였으며, 첨가되는 oil로는 linoleic acid의 함량이 높은 대두유(51.0\%)와 linolenic acid의 함량이 높은 아마유(59.2\%)가 이용되었다(Table 1). 각각의 처리구를 매 시험 당 3반복으로 하여 실시하였고, 동일한 조건에 서 3회 반복하여 시험을 실시하였다.

Table 1. Composition of $\mathrm{C}_{18}$-fatty acids of soybean oil and flaxseed oil

\begin{tabular}{lcc}
\hline \multirow{2}{*}{ Fatty acids } & \multicolumn{2}{c}{ Concentration (\%) } \\
\cline { 2 - 3 } & Soybean oil & Flaxseed oil \\
\hline \hline Stearic acid $\left(\mathrm{C}_{18: 0}\right)$ & 6.1 & 2.8 \\
Oleic acid $\left(\mathrm{C}_{18: 1)}\right)$ & 23.8 & 16.9 \\
Linoleic acid $\left(\mathrm{C}_{18: 2}\right)$ & 51.0 & 13.9 \\
Linolenic acid $\left(\mathrm{C}_{18: 3}\right)$ & 5.4 & 59.2 \\
\hline
\end{tabular}

\section{2. 배양액의 준비 및 배양}

(1) 반추위액의 준비

배양을 위한 반추위액은 반추위에 cannula가 장착된 Holstein 암소 2 두에서 채취하였다. 사료 는 1 일 $10 \mathrm{~kg}$ (건물기준)의 한우 비육 전기용 시판 배합사료와 세절한 조사료(볏짚)를 $40: 60$ 의 비율로 하여 아침(07:00)과 저녁(18:00)에 $5 \mathrm{~kg}$ (DM basis)씩 나누어 급여하였다. 배합사 료의 조단백질, 조지방 및 $\mathrm{TDN}$ 함량은 각각 13.7, 4.96 및 70\% (DM basis)였고 볏짚의 경우 조단백질, 조지방 및 조섬유 함량은 각각 3.61 , 
3.22 및 65.7\% (DM basis)였다. 아침 사료급여 3시간 후에 반추위액을 채취한 다음, 이를 12 겹의 거즈로 거르고, 다시 고형물과 거른 반추 위액을 1:2의 비율로 혼합하여 Waring blender (Fisher Co.)로 3분간 혼합하였다. 혼합된 반추 위 내용물을 다시 12 겹의 거즈로 걸러 배양을 위한 반추위액으로 이용하였으며, 준비된 반추 위액은 10 초간 고순도의 $\mathrm{CO}_{2}$ gas로 충진 된 다음 배양액 준비 전까지 $39^{\circ} \mathrm{C}$ 의 온도로 유지 되었다.

(2) 배양액 준비 및 배양

반추위액과 배지(Table 2)를 1:4(v/v)의 비율로 혼합하여 배양액으로 이용하였는데, 이 배양액

Table 2. Composition of basal medium ${ }^{1)}$

\begin{tabular}{lc}
\hline \multicolumn{1}{c}{ Components } & in $1,000 \mathrm{ml}$ \\
\hline \hline Salt solution $^{2}$ & $500 \mathrm{ml}$ \\
Cysteine- $\mathrm{HCl} \cdot \mathrm{H}_{2} \mathrm{O}$ & $0.5 \mathrm{~g}$ \\
Rumen fluid $^{3)}$ & $300 \mathrm{ml}$ \\
Dextrose & $1.0 \mathrm{~g}$ \\
Arabinose & $1.0 \mathrm{~g}$ \\
Fructose & $0.5 \mathrm{~g}$ \\
Pyruvate & $1.0 \mathrm{~g}$ \\
Peptone & $0.5 \mathrm{~g}$ \\
(NH $\left._{4}\right)_{2} \mathrm{SO}_{4}$ & $0.5 \mathrm{~g}$ \\
Yeast extract & $0.5 \mathrm{~g}$ \\
Hemin solution & \\
Distilled water to & $10 \mathrm{ml}$ \\
\hline
\end{tabular}

1) $\mathrm{pH}$ of medium was adjusted to 6.5

2) Salt solution consists of $2.0 \mathrm{~g} \mathrm{NaCl}, 1.0 \mathrm{~g} \mathrm{~K}_{2} \mathrm{HPO}_{4}$, $1.0 \mathrm{~g} \mathrm{KH}_{2} \mathrm{PO}_{4}, 0.265 \mathrm{~g} \mathrm{CaCl}_{2} \cdot 2 \mathrm{H}_{2} \mathrm{O}, 0.409 \mathrm{~g} \mathrm{MgSO}_{4}$ - $7 \mathrm{H}_{2} \mathrm{O}, \quad 10.0 \mathrm{~g} \mathrm{NaHCO}_{3}$ in $1,000 \mathrm{ml}$ distilled water

3) Rumen fluid was obtained from cattle fed $8 \mathrm{~kg}$ of hay $(60 \%)$ and concentrate (40\%) daily, and after being strained through twelve layers of cheese cloth the rumen fluid was stored frozen $-20^{\circ} \mathrm{C}$. It was melted and centrifuged at 3,000 rpm for 10 min to remove the large particle. The supernatant was centrifuged again at $18,000 \mathrm{rpm}$ for $20 \mathrm{~min}$ after being autoclaved.

4) $50 \mathrm{mg}$ Hemin was dissolved in $1 \mathrm{ml} 1 \mathrm{~N} \mathrm{NaOH}$ and made to $10 \mathrm{ml}$ with distilled water
에 30 초간 $\mathrm{CO}_{2}$ gas를 충진시켰으며, 배양이 시작될 때까지 항온수조를 이용하여 $39^{\circ} \mathrm{C}$ 로 유지되었다. 탄수화물원의 공급을 위해 glucose, cellobiose, soluble starch를 1:1:1(w/w/w)의 비율 로 혼합한 탄수화물원을 배양액 $(150 \mathrm{ml})$ 의 $0 \%$, $0.3 \%, 0.6 \%$ 그리고 $0.9 \%(\mathrm{w} / \mathrm{v})$ 수준으로 배양용 $300 \mathrm{ml}$ 의 삼각플라스크에 넣었다. 대두유와 아마 유의 첨가는 Wang 등(2002a)의 방법을 이용하였 다. 즉, 대두유와 아마유 $60 \mathrm{mg}$ 을 chloroform 50 $\mathrm{ml}$ 에 용해한 후 여기에 다시 $1 \mathrm{~g}$ 의 cellulose powder를 넣고 잘 섞은 다음 질소가스를 주입 하면서 chloroform을 증발시킨 후에 이용하였 다. 준비된 배양액 $(150 \mathrm{ml})$ 을 탄수화물이 첨가 된 각각의 배양용 플라스크에 넣고, 여기에 대 두유 또는 아마유가 흡착된 cellulose powder $(1.06 \mathrm{~g})$ 를 넣은 다음 30 초간 $\mathrm{CO}_{2}$ gas로 충진한 후 진탕배양기(Won Pung Scientific Co)를 이용 하여 $39^{\circ} \mathrm{C}$ 에서 12 시간동안 배양을 하였다. 배 양기간 동안 진탕속도는 120 times/min으로 유 지되었다.

\section{(3) 시료의 채취 및 분석}

발효특성 조사를 위한 배양액은 배양 전(0 시간)과 시작 후 3 시간, 6 시간, 그리고 종료 시(12 시간)에 채취되었다. VFA 분석을 위해 4 $\mathrm{ml}$ 의 배양액을, 그리고 ammonia-N 농도 측정을 위해 $1 \mathrm{ml}$ 의 배양액을 취하여 분석까지 $-20^{\circ} \mathrm{C}$ 에서 냉동보관 하였다. VFA 분석용 배양액 4 $\mathrm{ml}$ 에 $1 \mathrm{ml}$ 의 $25 \%$ phosphoric acid를 첨가하여 보관하였다.

배양액의 $\mathrm{pH}$ 는 배양 전과 각각의 시료 채취 시에 측정되었고, ammonia-N의 농도는 Fawcett과 Scott(1960)의 방법을 이용하여 spectrophotometer (Berkman, DU-650)로 분석되었다. VFA는 냉동 보관된 시료를 해동한 다음 적량을 취하여 0.2 $\mathrm{ml}$ 의 $2 \%$ pivalic acid를 internal standard로 넣어 잘 혼합하고 $15,000 \times \mathrm{g}$ 에서 15 분간 원심분리 한 후, 상층액을 취하여 $30 \mathrm{~m}$ 의 capillary column (NUKOL ${ }^{\mathrm{TM}}, 0.25 \mathrm{~mm}$ i.d., Supelco Co.)이 장착된 gas chromatograph(GC, HP5890 series II, Hewlett Packard Co.)로 분석되었다.

배양 개시 후 3 시간과 배양이 끝난 12 시간 
배양 후에 지방산 분석을 위해 배양액을 냉동 건조 하였으며, Folch 용액(Folch 등, 1957)을 이용하여 시료의 지질을 추출하였다. 추출된 지방산을 Lepage와 Roy(1986)의 방법에 따라 methylation을 시켰고, 준비된 시료의 지방산은 gas chromatograph를 이용하여 분석하였다. CLA 분석에 사용된 column으로 $100 \mathrm{~m}$ 의 capillary column(Supleco $\mathrm{SP}^{\mathrm{TM}}-2560,0.25 \mathrm{~mm}$ I.d.)이 이용 되었고, carrier gas로는 헬륨가스가 이용되었다. 주입부(injector)와 FID 검출기의 온도는 각각 $250^{\circ} \mathrm{C}$ 와 $260^{\circ} \mathrm{C}$ 로 유지 되었으며, split ratio는 $1 / 50$ 로 유지되었다. 또한 oven의 program을 초 기 $170^{\circ} \mathrm{C}$ 에서 5 분간 정지시킨 후에, $220^{\circ} \mathrm{C}$ 가 될 때까지 $4^{\circ} \mathrm{C} / \mathrm{min}$ 의 속도로 온도를 증가시켰 으며, $220^{\circ} \mathrm{C}$ 에서 40 분간 유지시키면서 분석하 였다.

(4) DATA의 분석

조사된 일체의 성적은 SAS 통계 팩키지 (1985)의 GLM procedure를 이용하여 분석하였 으며, 처리간 성적은 대두유 첨가구와 아마유 첨가구, 탄수화물 수준간 그리고 oil 첨가구와 탄수화물 첨가수준간의 상호작용을 orthogonal comparison으로 분석하였다.

\section{III. 결 과}

각각의 oil을 첨가하여 배양하였을 때, 탄수 화물원의 첨가수준이 증가될수록 배양액 내 의 $\mathrm{pH}$ (Fig. 1 및 Fig. 2)와 ammonia-N (Fig. 3 및 Fig. 4) 농도는 낮았다. 탄수화물 첨가수준 에 따른 $\mathrm{pH}$ 와 ammonia- $\mathrm{N}$ 농도에서의 효과는 배양 후 3 시간 보다, 6 시간과 12 시간이 경과 된 후에 더욱 뚜렷하게 나타났다 $(\mathrm{P}<0.05$ $\mathrm{P}<0.001)$.

배양 초기단계인 3시간이 경과하였을 때, 배 양액 내 휘발성 지방산의 조성 및 농도는 지방 산조성이 다른 oil로 인한 영향을 받지 않았으 나, 배양 개시 6시간 후 acetate $\left(\mathrm{C}_{2}\right)$ 의 농도는 대 두유 첨가구 보다 아마유 첨가구에서 높았다 $(\mathrm{P}<0.05)$. 반면, propionate $\left(\mathrm{C}_{3}\right)$ 의 농도는 대두유 첨가구에서 높은 $(\mathrm{P}<0.01)$ 것으로 나타났다. 이에

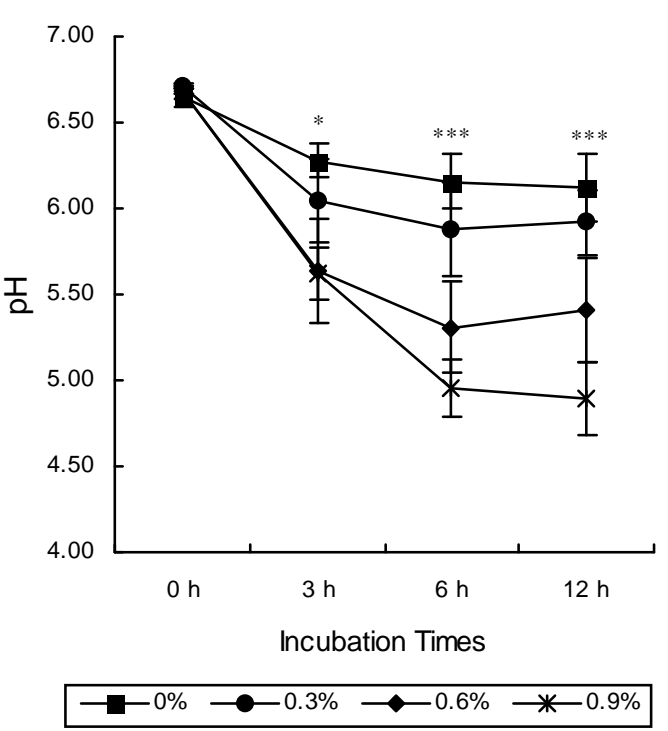

Fig. 1. $\mathrm{pH}$ in culture solution as influenced by carbohydrate levels when incubated with soybean oil.

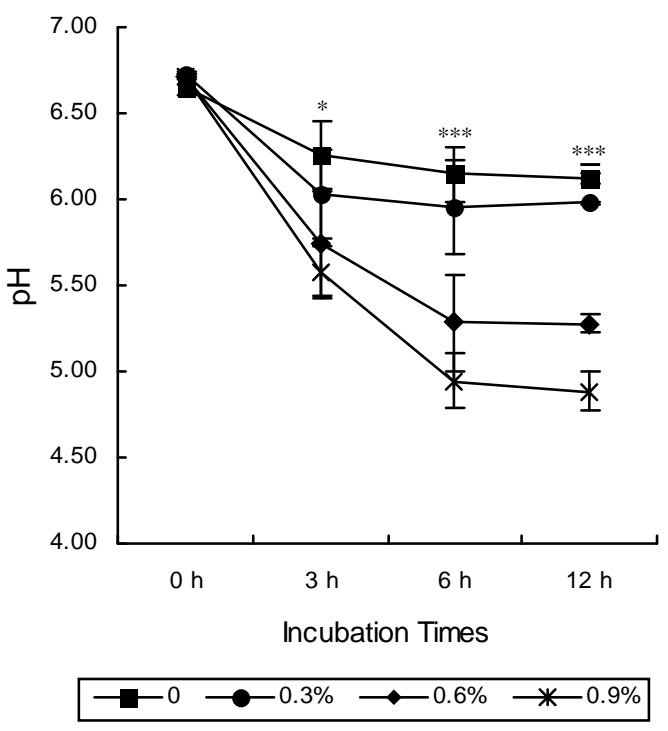

Fig. 2. $\mathrm{pH}$ in culture solution as influenced by carbohydrate levels when incubated with flaxseed oil.

따라 $\mathrm{C}_{2} / \mathrm{C}_{3}$ 는 아마유 첨가구(2.76 3.62)가 대두 유 첨가구(2.41 3.48)에 비해 높았다 $(\mathrm{P}<0.05)$. 그 러나 배양이 종료된 12 시간에서의 배양액 내 


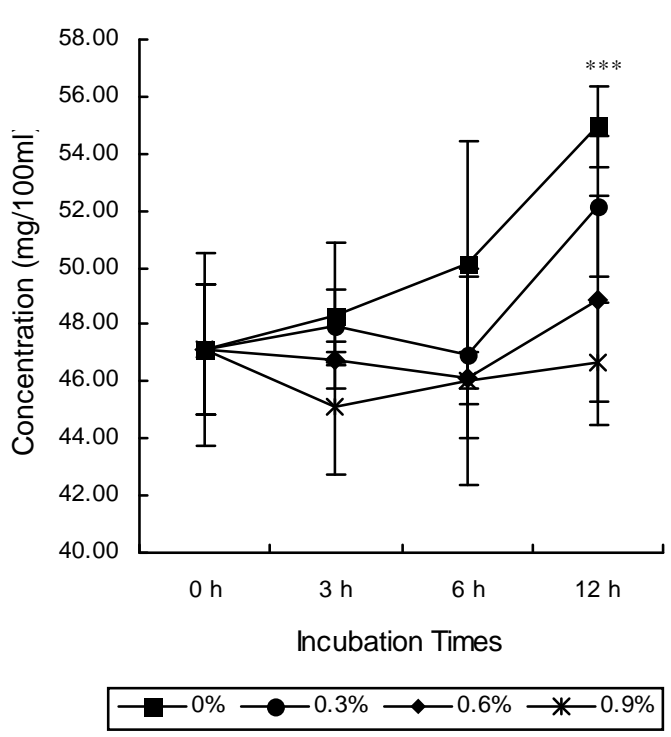

Fig. 3. Concentration of ammonia-N in culture solution as influenced by carbohydrate levels when incubated with soybean oil.

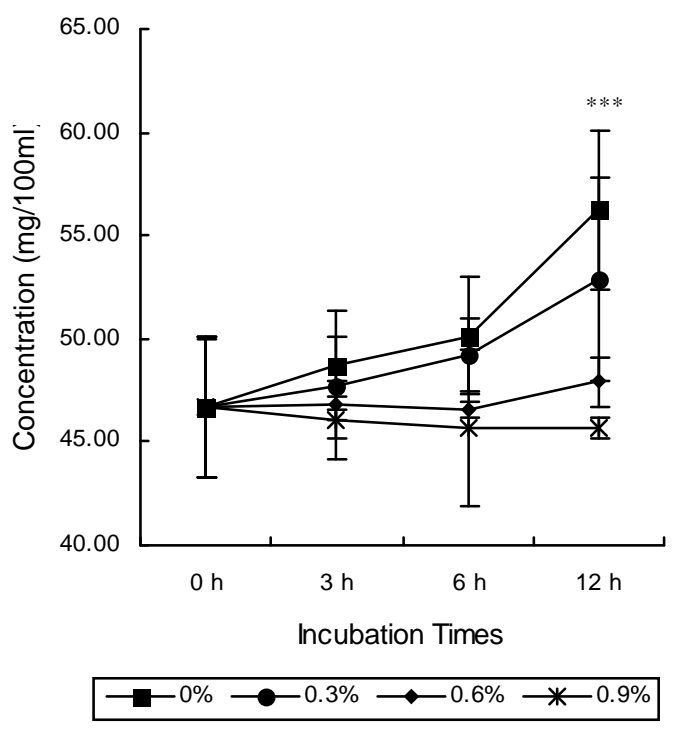

Fig. 4. Concentration of ammonia-N in culture solution as influenced by carbohydrate levels when incubated with flaxseed oil.

휘발성지방산 조성은 oil 종류에 의한 영향을 받지 않았다(Table 3).
배양이 진행됨에 따라 배양액 내 일부 VFA 의 농도 및 조성은 탄수화물원의 수준에 의해 서도 영향을 받았는데, 배양 개시 3 시간 후에는 탄수화물원의 첨가수준이 증가됨에 따라 total $\mathrm{VFA}$ 농도도 증가되었다 $(\mathrm{P}<0.05)$. 탄수화물원 의 첨가량이 증가됨에 따라 propionate의 조성 비율 역시 다소 증가되는 경향이었다. 배양 개 시 후 6시간이 경과하였을 때, 탄수화물원의 첨가수준이 증가됨에 따라 총 휘발성지방산 (total VFA)의 농도 $(\mathrm{P}<0.05)$ 와 propionate의 조성 비율 $(\mathrm{P}<0.001)$ 역시 점차 증가되었으나 butyrate $(\mathrm{P}<0.001)$ 의 조성 비율과 $\mathrm{C}_{2} / \mathrm{C}_{3}(\mathrm{P}<0.001)$ 는 감소 되었다(Table 3). 배양이 종료된 12시간에서의 배양액은 탄수화물원의 첨가수준이 증가됨에 따라 total $\mathrm{VFA}$ 의 농도 $(\mathrm{P}<0.01)$ 와 propionate $(\mathrm{P}<0.001)$ 및 butyrate $(\mathrm{P}<0.001)$ 의 조성 비율 역 시 증가되었으나, acetate $(\mathrm{P}<0.001)$, iso-valerate $(\mathrm{P}<0.001)$, 및 valerate $(\mathrm{P}<0.001)$ 조성 비율 및 $\mathrm{C}_{2} / \mathrm{C}_{3}(\mathrm{P}<0.001)$ 는 감소되었다(Table 3$)$.

배양액에 지방산 조성이 다른 대두유와 아마 유를 첨가한 후 배양시간이 경과됨에 따라 배 양액의 지방산 조성이 다양하게 변화된 것으로 나타났다. 배양 초기(배양 개시 후 3시간)의 배 양액내 oleic acid의 조성 비율은 아마유 첨가 시(8.76 18.86\%) 보다 대두유를 첨가했을 때 (17.52 23.23\%) 더 높았으나 $(\mathrm{P}<0.01)$, linoleic acid의 조성 비율은 아마유 첨가구(20.06 $22.59 \%$ )가 대두유 첨가구(2.64 4.19\%)에 비하 여 약 5 배 이상 높았다 $(\mathrm{P}<0.001)$. 배양 개시 후 시간이 경과함에 따라, 배양액 내 palmitic acid 의 조성 비율은 아마유(12.11\% 15.84\%)를 첨 가했을 때보다 대두유(16.96\% 18.26\%)를 첨가 하였을 때 높았고 $(\mathrm{P}<0.01)$, oleic acid의 조성 비 율도 대두유(18.71\% 22.6\%) 첨가 시 아마유 $(10.32 \%$ 12.76)를 첨가할 때 보다 더 높은 것 으로 나타났다 $(\mathrm{P}<0.001)$. Trans- $\mathrm{C}_{18: 1}$ 의 조성 비 율 또한 대두유 첨가 시(6.90\% 12.45\%) 보다 아마유를 첨가하였을 때(2.10\% 5.42\%) 더 높았 다 $(\mathrm{P}<0.01)$. 특히, linoleic acid의 조성 비율은 대두유 첨가구(2.80 4.02\%) 보다 아마유 첨가 구(18.25 24.36\%)에서 증가된 $(\mathrm{P}<0.001)$ 것으 로 나타났다. 배양이 종료된 12시간 후, 아마 
유 첨가구에 비하여 대두유 첨가구에서 stearic acid(40.34 47.31\%), oleic acid (15.93 21.06\%) 그리고 trans-C18:1 (6.90 12.45\%)의 조성 비율 이 높았다 $(\mathrm{P}<0.01 \sim \mathrm{P}<0.001)$. 반면, 불포화도가 높은 linoleic acid(2.14 3.93\%) 및 linolenic acid (0.19 0.35\%)의 조성 비율은 대두유 첨가구 에서 낮은 것으로 나타났다 $(\mathrm{P}<0.01 \sim \mathrm{P}<0.001$, Table 4).

한편, 배양액의 지방산은 배양초기(배양 후 3 시간)에는 탄수화물원의 첨가로 인한 조성의 변 화는 없었지만 배양이 끝난 12 시간 후, 배양액 내 탄수화물원의 첨가수준이 증가될수록 stearic $\operatorname{acid}(\mathrm{P}<0.01)$ 와 총 $\mathrm{CLA}(\mathrm{P}<0.01)$ 의 조성 비율은 감소되었으며 $(\mathrm{P}<0.01)$, trans $-11 \mathrm{C}_{18: 1}$ 의 조성 비율 은 탄수화물원의 첨가수준이 $0.3 \%$ 및 $0.6 \%$ 에서 는 감소되었지만 $0.9 \%$ 에서는 증가되었다 $(\mathrm{P}<0.05)$. 탄수화물원의 첨가수준이 증가됨에 따라 llinoleic acid의 조성 비율 역시 증가되었다 $(\mathrm{P}<0.01)$.

일부 지방산은 첨가되는 oil과 탄수화물원의 첨가수준 간 상호작용이 있었는데, 배양 개시 후 3시간이 경과하였을 때 배양액 내 oleic acid 조성 비율은 대두유 첨가구에서는 탄수화물원 의 첨가수준이 증가됨에 따라 증가되었지만, 아마유 첨가구에서는 탄수화물원의 첨가수준이 증가될수록 oleic acid 조성 비율이 증가되는 경 향을 보였을 뿐이었다. 배양이 끝난 12시간 후 oleic $\operatorname{acid}(\mathrm{P}<0.05)$ 와 linolenic $\operatorname{acid}(\mathrm{P}<0.01)$ 의 조 성 비율은 대두유 첨가구에서 탄수화물원의 첨 가수준이 증가될수록 증가되었지만, 아마유 첨 가구에서는 오히려 감소되었다. 그러나 linolenic acid의 조성비율은 아마유 첨가시 조성비율이 높았고, 그 조성비율의 변화 역시 컸으나, 대두 유 첨가시는 조성비율 및 조성비율의 변화 정 도가 낮았다 $(\mathrm{P}<0.05$, Table 4$)$

\section{IV. 고 찰}

반추위 미생물에 의한 불포화지방산의 biohydrogenation 정도에 따라 중간 대사물질들 즉, $\mathrm{C}_{18: 0}$, trans $-\mathrm{C}_{18: 1}, \mathrm{C}_{18: 2}$ 과 CLAs 등의 조성이 변화 되는데, 이들 중간 대사물질들은 흡수되어 직 접 또는 변형되어 고기 내 지방으로 저장 되거
나 유지방형태로 분비된다(Demeyer와 Doreau, 1999; Chilliard 등, 2000).

일반적으로 반추위액의 $\mathrm{pH}$ 는 섭취된 사료의 종류와 섭취량, 타액 내 carbonate의 완충능력 그리고 생성된 $\mathrm{VFA}$ 의 흡수율 등과 밀접한 관 계를 가지고 있다(Martin과 Jenkins, 2002). 특히 섭취된 다량의 농후사료는 반추위 미생물의 발 효에 의해 VFA, 젖산 및 메탄가스와 암모니아 등을 생성하는데, 이들 발효부산물 들 중에서 $\mathrm{VFA}$ 와 젖산은 반추위내 $\mathrm{pH}$ 를 저하시키는데 큰 영향을 하며, 그에 따라 B. fibrisolvens와 같 은 섬유소 분해 박테리아의 활동이 저해된다고 하였다(Choi 등, 2005). Figure 1 및 2, 그리고 Table 3에서 보는 바와 같이 배양액의 $\mathrm{pH}^{\circ}$ 와 $\mathrm{VFA}$ 의 총 농도 및 조성은 탄수화물원의 첨가 수준에 따라서 큰 차이가 있었는데, 두 종류의 oil을 첨가한 배양액 모두 탄수화물의 첨가로 인하여 $\mathrm{pH}$ 가 낮아졌다 $(\mathrm{P}<0.05 \sim \mathrm{P}<0.001)$. 낮아 진 $\mathrm{pH}$ 는 탄수화물 첨가수준이 증가됨에 따라 총 $\mathrm{VFA}$ 의 농도 역시 증가되어 나타나는 현상 과 관련이 있는 것으로 보인다. 또한 배양 초 기(3h)를 제외하고는 불포화도가 높은 아마유 첨가시 대두유 첨가시 보다 총 VFA 생성량이 감소되었는데(Table 3), 이러한 결과는 대두유 에 비하여 아마유내 linolenic $\operatorname{acid}\left(\mathrm{C}_{18: 3}\right)$ 와 같이 불포화도가 높은 지방산(Table 1)이 첨가됨으로 서 가용성 탄수화물의 발효를 감소시켰으며, 아울러 propionate 생성량이 감소되었기 때문인 것으로 여겨진다. 이러한 현상은 배양 후 6시 간이 경과하였을 때 현저하게 나타났다.

Devendra와 Lewis(1974)는 불포화지방산이 반 추위미생물에 독소로 작용하여 미생물 군총의 변화를 가져옮은 물론 사료 분해를 저해할 수 있으며, 이러한 현상은 지방산의 불포화도가 높을수록 심화될 수 있다고 보고한 바 있다.

배양이 완료된 12 시간 후의 배양액 내 ammonia- $\mathrm{N}$ 의 농도는 탄수화물 첨가수준이 증가될 수록 낮았는데, 이러한 결과는 in vitro의 제한 된 조건 하에서 생성된 ammonia-N이 발효가 활발하게 일어나는 처리구의 미생물에 의해 ammonia-N의 이용이 증가된 때문인 것으로 사 료된다. 
Choi et al. ; Effect of Oil Source and Carbohydrate Levels on CLA Production 
Choi et al. ; Effect of Oil Source and Carbohydrate Levels on CLA Production 
본 실험에서 탄수화물원의 첨가수준이 증가 될수록 배양액 내에서의 $\mathrm{pH}$ 는 낮아지고 총 $\mathrm{VFA}$ 의 농도는 증가되었으며, cis-9, trans-11 CLA 및 총 CLA 조성 비율의 감소가 수반됨을 확인하였다. 한편, Jiang 등(1998)은 낮은 $\mathrm{pH}$ 에 서도 성장이 활발한 propionate 생성박테리아가 trans-10, cis-12 CLA를 생성한다고 하였지만, 본 실험에서는 낮아진 $\mathrm{pH}$ 로 인하여 trans- 10 , cis-12 CLA의 조성 비율에 영향하지 않은 것으 로 보이며, 그 보다는 $\mathrm{pH}$ 가 저하됨에 따라 cis-9, trans-11 CLA를 생성하는 섬유소분해 박테리아 의 활성을 저해하여 cis-9, trans-11 CLA의 조성 비율에 더 영향 한 것을 사료된다. 배양이 종 료된 배양액에서의 $\mathrm{C}_{18: 2}$ 의 농도는 $\mathrm{C}_{18: 2}$ 가 다량 함유된 대두유 첨가에 비하여 $\mathrm{C}_{18: 3}$ 이 다량 함 유된 아마유 첨가구에서 높았는데 $(\mathrm{P}<0.001)$, 이 러한 현상은 Figure 2에서 보는 바와 같이 배양 이 시작된 지 3 시간이 지났을 때, 일부 처리구 에서 $\mathrm{pH}$ 가 5.5 가까이 떨어지기 때문에 미생물 들에 의한 bio-hydrogenation이 저해되어 더 이 상 반응이 진행되지 않은 것으로 보인다.

Kepler와 Tove (1967)에 보고에 의하면, biohydrogenation은 일반적으로 반추위액 혹은 배 양액의 $\mathrm{pH}$ 가 일반적인 범위 $(6.5 \pm 0.2)$ 내에 있 지 않으면 미생물 세포막의 안정성에 이상이 생기며, 그에 따라 세포막에 존재하는 효소의 반응에 영향을 주어 bio-hydrogenation rate가 감 소하게 된다고 하였다. cis-9, trans-11 CLA를 생성하는 것으로 알려진 B. fibrisolvens 는 $\mathrm{pH}$ 가 저하됨에 따라 섬유소에 대한 부착능력을 상실 하는데, 이에 따라 B. fibrisolvens의 증식은 물 론 반추위 내에서의 bio-hydrogenation 작용도 감 소될 수 있다(Kopecny 등, 1983). Wang과 Song (2003)도 이와 비슷한 보고를 하였는데, 배양액 의 $\mathrm{pH}$ 를 4.5, 5.6, 6.1 그리고 6.9로 유지하며 배양한 결과, 낮은 $\mathrm{pH}$ 보다는 높은 $\mathrm{pH}$ 에서 cis-9, trans-11 CLA의 농도가 증가되었다고 하 였다. Choi 등(2005)은 반추위액 혹은 배양액 내의 $\mathrm{pH}$ 와 cis-9, trans- 11 CLA는 양의 상관관 계 $\left(r^{2}=0.88\right)$ 를 보였으며, trans-10, cis-12 CLA 는 음의 상관관계를 보였다고 하였다.

반추미생물에 의한 bio-hydrogenation은 탄수화
물원의 첨가수준에 따라 나타나는 발효특성에 의해 영향을 받기도 하였지만, 첨가된 oil에 의한 영향도 받은 것으로 보인다. Linolenic acid와 같 은 불포화도가 높은 지방산을 많이 함유한 아마 유의 첨가가 대두유 첨가에 비하여 반추미생물의 성장 및 활동을 저해하는 것으로 보인다. Loor 등(2005)은 젖소에게 아마유와 같이 불포화도가 높은 식물성 기름을 사료에 $5 \%$ 첨가하여 급여한 결과 반추위 미생물들에 의한 bio-hydrogenation 이 감소된다고 하였다. 본 실험에도 아마유 첨가 구에서 대두유 첨가구에 비하여 linoleic acid의 함량이 매우 높았으며, 반대로 stearic acid의 함 량은 대두유 첨가구에 비하여 낮았다( $\mathrm{P}<0.01)$.

이상의 결과들을 종합하면, linoleic acid가 많 이 함유된 대두유와 linolenic acid가 많이 함유 된 아마유를 배양액에 각각 첨가하고 탄수화물 원의 첨가수준을 증가시키며 배양한 결과, 두 오일을 첨가한 배양액에서 공히 탄수화물원의 첨가수준이 증가될수록 배양액 내의 $\mathrm{pH}$ 가 낮 아졌으며, 낮아진 $\mathrm{pH}$ 에 의해서 cis-9, trans-11 CLA의 생성량 및 bio-hydrogenation이 감소된 것으로 사료된다. 특히 linolenic acid가 다량 함 유된 oil(아마유)을 첨가하여 배양하였을 때, 탄 수화물원의 첨가수준이 높아짐으로 인해 낮아 진 $\mathrm{pH}$ 는 반추미생물에 의한 bio-hydrogenation 반응을 감소시켜 배양액 내의 linoleic acid 조 성 비율을 높일 수 있다는 가능성을 확인하였 다.

$$
\text { V. 요 약 }
$$

본 실험은 대두유 또는 아마유를 in vitro 방법으로 배양 할 때, 탄수화물원의 첨가수준 이 반추위 박테리아에 의한 bio-hydrogenation 과 CLA 생성에 미치는 효과를 조사하였다. 4수준 $(0 \%, 0.3 \%, 0.6 \%$ 그리고 $0.9 \%, \mathrm{w} / \mathrm{v})$ 의 혼합된 탄수화물원(glucose, cellobiose, soluble starch, 1:1:1, w/w/w)과 두 종류의 oil을 cellulose powder에 흡착시킨 형태로 각각 $60 \mathrm{mg}$ 씩 인 공타액 $(120 \mathrm{ml})$ 과 반추위액 $(30 \mathrm{ml})$ 이 혼합된 배양액 $(150 \mathrm{ml})$ 에 넣은 다음 $39^{\circ} \mathrm{C}$ 에서 12 시 간동안 혐기적으로 배양하였다. 
배양액의 $\mathrm{pH}$ 와 암모니아 농도는 두 종류 oil 을 첨가한 배양액 모두에서 탄수화물원의 첨가 수준이 높을수록 $\mathrm{pH}$ 와 암모니아 농도가 낮았다 $(\mathrm{P}<0.05)$. 탄수화물원의 첨가 수준이 증가할수록 total VFA 생성량 역시 증가되었으나 $(\mathrm{P}<0.01)$ 첨 가한 oil 간의 차이는 없었다. 배양시간이 경과 됨에 따라 탄수화물원의 첨가수준이 높을수록 propionate의 조성비율이 증가된 반면 $(\mathrm{P}<0.001)$ acetate와 butyrate의 조성비율은 감소되었다.

배양 후 3시간이 경과하였을 때 배양액 내 oleic acid의 조성비율은 대두유에 비하여 아 마유를 첨가한 배양액에서 낮았으나 $(\mathrm{P}<0.001)$ linoleic acid의 비율은 높았다 $(\mathrm{P}<0.001)$. 이와는 달리 탄수화물원의 수준이 증가될수록 stearic $\operatorname{acid}(\mathrm{P}<0.05), \operatorname{CLA}(\mathrm{P}<0.01)$ 및 cis-9, trans-11 $\mathrm{CLA}(\mathrm{P}<0.001)$ 의 조성비율은 감소되었으나, linoleic acid의 조성 비율은 증가되었다 $(\mathrm{P}<0.05)$. Linolenic acid의 조성비율에 있어서는 첨가된 oil의 종류 와 첨가된 탄수화물원의 수준간의 상호작용이 있는 것으로 나타났는데 $(\mathrm{P}<0.001), 12$ 시간의 배 양종료 후 대두유 첨가구에 비해 아마유 첨가 구에서 stearic acid $(\mathrm{P}<0.01)$, oleic $\operatorname{acid}(\mathrm{P}<0.001)$, 그리고 trans $-11 \mathrm{C}_{18: 1}(\mathrm{P}<0.01)$ 의 조성비율이 감 소된 반면, linoleic $\operatorname{acid}(\mathrm{P}<0.001)$ 와 linolenic $\operatorname{acid}(\mathrm{P}<0.01)$ 의 조성비율은 증가되었다. 탄수 화물원의 첨가수준이 증가될수록 stearic acid 와 총 $\mathrm{CLA}$ 의 조성비는 감소되었으나 $(\mathrm{P}<0.01)$, trans-11- $\mathrm{C}_{18: 1}(\mathrm{P}<0.05)$ 와 linoleic $\operatorname{acid}(\mathrm{P}<0.01)$ 의 조성비율은 증가되었다. 배양 12 시간 후 배양 액 내의 oleic acid $(\mathrm{P}<0.05)$, linoleic $\operatorname{acid}(\mathrm{P}<0.05)$ 및 linolenic $\operatorname{acid}(\mathrm{P}<0.01)$ 의 조성비율에 있어서 는 첨가한 oil의 종류와 첨가한 탄수화물원의 수준간의 상호작용이 있었는데, 탄수화물원의 첨가수준이 감소됨에 따라 cis-9, trans-11 CLA 와 trans-10, cis-12 CLA의 조성비 역시 감소 되는 경향이었으나 첨가한 oil의 종류에 대한 영향은 거의 받지 않았다. 본 실험의 결과를 종합해 볼 때, 탄수화물의 첨가수준과 oil의 첨가는 반추미생물의 bio-hydrogenation 작용 및 CLA 생성에 영향할 수 있는 것으로 여겨 진다.
VI. 사 사

본 연구는 농촌진흥청 바이오그린21사업(과제 번호 : 20050401-034-701-136-01-00)의 지원에 의 해 이루어진 것임.

\section{VII. 인 용 문 헌}

1. Banni, S. and Martin, J. C. 1998. Conjugated Linoleic Acid and Metabolites. In Trans Fatty Acids in Human Nutrition. pp. 261-302. Dundee, Scotland, The Oily Press, Ltd.

2. Bauman, D. E. and Griinari, J. 2003. Nutritional Regulation of Milk Fat Synthesis. Annu. Rev. Nutr. 23:203-227.

3. Bessa, R. J., Santos-Silva, J., Ribeiro, J. M. and Portugal, A. V. 2000. Reticulo-Rumen Bio-hydrogenation and the Enrichment of Ruminal Edible Products with Linoleic Aid Conjugated Isomers. Appl. Environ. Microbiol. 63:201-211.

4. Chilliard, Y., Ferlay, A., Mansbridge, R. and Doreau, M. 2000. Ruminant Milk Fat Plasticity: Nutritional Control of Saturated, Polyunsaturated, trans and Conjugated Fatty Acids. Ann. Zootech. 49:181-205.

5. Choi, S. H. and Song, M. K. 2005. Effect of $\mathrm{C}_{18}$-Polyunsaturated Fatty Acids on Their Direct Incorporation into the Rumen Bacterial Lipids and CLA Production In Vitro. Asian-Aust. J. Anim. Sci. Vol 18, No 4. 512-515.

6. Choi, S. H., Wang, J. H., Kim, Y. J., Oh, Y. K. and Song, M. K. 2006. Effect of Soybean Oil Supplementation on the Contents of Plasma Cholesterol and cis9, trans11-CLA of the Fat Tissues in Sheep. Asian-Aust. J. Anim. Sci. Vol 19:679-683.

7. Choi, N. J., Imm, J. Y., Oh, S. J., Kim, B. C., Hwang, H. J. and Kim, Y. J. 2005. Effect of $\mathrm{pH}$ and Oxygen on Conjugated Linoleic Acid(CLA) Production by Mixed Rumen Bacteria from Cows Fed High Concentrate and High Forage diets. Animal Feed Science and Technology. 123-124 :643-653. 
8. Cook, M. E., Miller, C. C., Park, Y. and Pariza, M. 1993. Immune Modulation by Altered Nutrient Metabolism: Nutritional Control of Immune-Induced Growth Depression. Poult. Sci. 72:1301-1305.

9. Demeyer, D. and Doreau, M. 1999. Targets and Procedures for Altering Ruminant Meat and Milk Lipids. Proc. Nutr. Soc. 58:593-607.

10. Devendra, C. and Lewis, D. 1974. The Interaction between Dietary Lipids and Fiber in the Sheep. Anim. Proc. 19:67-76.

11. Dhiman, T, R., Helmink, E. D., McMahon, D. J., Fife, R. L. and Pariza, M. W. 1999. Conjugated Linoleic Acid Content of Milk and Cheese from Cows Fed Extruded Oilseeds. J. Dairy. Sci. 82: 412-419.

12. Fallner, V., Sauer, F. D. and Kramer, J. K. G. 1997. Effect of Nigericin, Monensin, and Tetronasin on bio-hydrogenation in Continuous Flow-through Ruminal Fermenters. J. Dairy. Sci. 80:921-928.

13. Fawcett, J. K. and Scott, J. E. 1960. A Rapid and Precise Method for the Determination of Urea. J. Clin. Pathol. 13:156-163.

14. Folch, J., Lee, M. and Sloan-Stanley, G. H. 1957. A Simple Method for the Isolation and Purification of Total Lipids from Animal Tissue. J. Biol. Chem. 226:497-509.

15. Ha, Y. L., Grimm, N. K. and Pariza, M. W. 1987. Anticarcinogens from Fried Ground Beef: HeatAltered Derivatives of Linoleic Acid. Carcinogenesis. 8:1881-1887.

16. Harfoot, C. G. and Hazlewood, G. P. 1997. Lipid Metabolism in the Rumen. pages 382-426. In The Rumen Microbial Ecosystem. P. N. Hobson, ed. Chapman \& Hall, London, UK.

17. Harfoot, C. and Hazlewood, G. 1988. Lipid Metabolism in the rumen. In: Hobson, P.N.(Ed.), The Rumen Microbial Ecosystem. Elsevier, London, UK, p.285.

18. Jiang, J., Bjorck, L. and Fonden, R. 1998. Production of Conjugated Linoleic Acid by Dairy Starter Cultures. J. Appl. Microbiol. 85:95-102.

19. Kelly, M. L., Berrym, J. R., Ewyer, D. A., Griinari,
J. M., Choinard, P. Y., Vanamburgh, M. E. and Bauman, D. E. 1998. Dietary Fatty Acid Sources Affect Conjugated Linoleic Acid Concentrations in Milk from Lactating Dairy Cow. J. Nutr. 128: 881-885.

20. Kepler, C. R. and Tove, S. B. 1967. Bio-hydrogenation of Unsaturated Fatty Acids. 3. Purification and Properties of a Linoleate delta-9-cis, delta11isomerase from Butryrivibrio fibrisolvens. J. Biol. Chem. 242:5686-5692.

21. Kopecny, J., Jurcuk, J. G. and Bartos, S. 1983. The Effect of $\mathrm{pH}$ and 1,4-Dithiothreitol on the Adhesion of Rumen Bacteria. Folia Microbiol. (Praha) 28:130-133.

22. Latham, M. J., Storry, J. E. and Sharpe, M. E. 1972. Effect of Low-Roughage Diets on the Microflora and Lipid Metabolism in the Rumen. Appl. Microbiol. 24:871-877.

23. Lee, K. N., Kritchevsky, D. and Pariza, M. W. 1994. Conjugated Linoleic Acid and Atherosclerosis in Rabbits. Atherosclerosis. 108:19-25.

24. Lepage, G. and Roy, C. C. 1986. Direct Transesterification of all Classes of Lipid in a One-step Reaction. J. Lipid Research. 27:114-121.

25. Loor, J. J., Ueda, K., Ferlay, A., Chillard, Y. and Doreau, M. 2005. Intestinal Flow and Digestibility of Trans-Fatty Acids and Conjugated Linoleic Acid(CLA) in Dairy Cows Fed a HighConcentrate Diet Supplemented with Fish Oil, Linseed Oil, or Sunflower Oil. Animal Feed Science and Technology. 119:203-225.

26. Martin, S. A. and Jenkins, T. C. 2002. Factors Affecting Conjugated Linoleic Acid and trans-11 $\mathrm{C}_{18: 1}$ Fatty Acid Production by Mixed Ruminal Bacteria. J. Anim. Sci. 80:3347-3352.

27. Park, Y. J., Albright, J., Storkson, J. M., Coom, M. E. and Pariza, M. W. 1997. Effects of Conjugated Linoleic Acid on Body Composition in Mice. Lipids. 32:853-858.

28. SAS., 1985. SAS User;s Guide : Statistical Analysis Systems Institute, Inc., Cary, NC.

29. Steinhart, C. 1996. Conjugated Linoleic Acid- the 
Good News About Animal Fat. J. Chem. Ed. 73:A 302-A 303.

30. Wang, J. H., Song, M. K., Son, Y. S. and Chang, M. B. 2002a. Addition Effect of Seed-Associated or Free Linseed Oil on the Formation of cis-9, trans-11 Conjugated Linoleic Acid and Octadecenoic Acid by Ruminal Bacteria in vitro. Asian-Aust. J. Anim. Sci. Vol 15, No. 8:1115-1120.

31. Wang, J. H., Song, M. K., Son, Y. S. and Chang, M. B. 2002b. Effect of Concentrate Level on the Formation of Conjugated Linoleic Acid and trans-Octadecenoic Acid by Ruminal Bacteria When Incubated with Oilseeds in vitro. Asian-Aust. J. Anim. Sci. Vol 15, No. 5:687-694.
32. Wang, J. H., Choi, S. H. and Song, M. K. 2003. Effects of Concentrate to Roughage Ration on the Formation of cis-9, trans-11 CLA and trans-11Octadecenoic Acid in Rumen Fluid and Plasma of Sheep When Fed High Oleic or High Linoleic Acid Oils. Asian-Aust. J. Anim. Sci. Vol 16, No. 11:1604-1609.

33. Wang, J. H. and Song, M. K. 2003. pH Affects the In Vitro Formation of cis-9, trans-11 CLA and trans-11 Octadecenoic Acid by Ruminal Bacteria When Incubated with Oilseeds. Asian-Aust. J. Anim. Sci. 16:1743-1748.

(접수일자 : 2006. 5. 25. / 채택일자 : 2006. 7. 13.) 